\title{
Multidrug Resistance-Associated Protein 6
}

National Cancer Institute

\section{Source}

National Cancer Institute. Multidrug Resistance-Associated Protein 6. NCI Thesaurus.

Code C116948.

Multidrug resistance-associated protein 6 (1503 aa, $\sim 165 \mathrm{kDa}$ ) is encoded by the human ABCC6 gene. This protein is involved in the active transport of xenobiotics and glutathione conjug ates across the plasma membrane. 